EGU21-7423

https://doi.org/10.5194/egusphere-egu21-7423

EGU General Assembly 2021

(c) Author(s) 2022. This work is distributed under

the Creative Commons Attribution 4.0 License.

\title{
Sediment transfer in the Rhône River Basin, Switzerland: the role of localized severe Alpine storm events on triggering turbidity currents in Lake Geneva
}

François Mettra ${ }^{1}$, Koen Blanckaert ${ }^{2}$, Ulrich Lemmin ${ }^{1}$, and David Andrew Barry ${ }^{1}$

${ }^{1}$ Ecological Engineering Laboratory, Lausanne Federal Institute of Technology, Lausanne, Switzerland (francois.mettra@epfl.ch)

${ }^{2}$ Institute of Hydraulic Engineering and Water Resources Management, TU Wien, Karlsplatz 13/222, A-1040 Vienna, Austria

In Lake Geneva, a deep peri-Alpine lake in Switzerland, the sublacustrine Rhône River delta presents a deep canyon, the Rhône Canyon. Previous studies and recent observations show that low-velocity underflows and high-velocity turbidity currents pass frequently in the Rhône Canyon. The former carry little sediment, are long-lasting, slow moving and typically occur in winter when the lake is destratified, whereas the latter are sediment-rich, short-lived and occasionally generate high velocities. In the present study, we revisit three different event types that can trigger turbidity currents in the Rhône Canyon: large-scale floods of the Rhône River, sublacustrine slides on the Rhône delta and short high concentration sediment transport events induced by localized severe storms in the Rhône watershed $\left(\sim 5500 \mathrm{~km}^{2}\right)$. Simultaneous observations of hyperconcentrated sediment-laden floods or debris flows in small sub-catchments (as small as $4 \mathrm{~km}^{2}$ ), suspended sediment concentration at the Rhône river mouth, and velocity profiles in the Rhône canyon demonstrate how localized storm events trigger turbidity currents in the canyon. Evidence that these turbidity currents can continue into the deep hypolimnion of Lake Geneva is provided. Preliminary estimations of the frequency of turbidity currents relative to their type of triggering and their contribution to the total sediment load discharged into Lake Geneva are discussed. 